\title{
Tsunamis revisited
}

\author{
Two tsunamis generated by distinct geohazards struck Indonesia within six months and killed thousands. Early-warning
} systems established after 2004 have not prevented devastation.

\begin{abstract}
$\mathrm{n}$ the arena of natural disasters, tsunami
hazards came centre-stage with the 2004

Boxing Day disaster in the Indian Ocean: a catastrophe that killed over 235,000 people from Indonesia to East Africa. Efforts have been focused on the prevention of future deaths by tsunami, by establishing an Indian Ocean early-warning tsunami network. Despite these efforts, two tsunamis that struck Indonesia in September and December 2018 resulted in over 2,000 deaths, one triggered by an earthquake near Palu, Sulawesi and the other by flank collapse during the eruption of Anak Krakatau volcano in the Sunda Strait. During both the Palu earthquake and the Anak Krakatau volcanic eruption in 2018, the local population apparently received limited warning of the impending tsunami in time for evacuation. These recent tsunamis have once again brought into sharp focus the destructive hazard that these deadly waves pose.
\end{abstract}

A tsunami is generated when a large volume of water is lifted up suddenly by earthquakes with a vertical component of crustal movement, landslides, submarine mass movements during volcanic eruptions or asteroid impacts. In the open ocean, they travel unobtrusively, but once they reach the coast they can affect coastal communities with devastating consequences.

The first of the two killer tsunamis of 2018, in September, was triggered by a magnitude- 7.5 earthquake on the Indonesian island of Sulawesi. In this issue of Nature Geoscience, an Article by Socquet and colleagues and an Article by Bao and colleagues argue that the 2018 Palu earthquake was unusual not only because it triggered a tsunami, but also because it ruptured at supershear speeds. The rupture speed may add another piece to the puzzle of how this particular tsunami was generated, as discussed in a News \& Views by Mai.

Scientific advances can help with quantifying risk. Progress in understanding the frequency of past tsunamis may help to quantify the vulnerability of coastal communities in Indonesia ${ }^{1}$. Forecast modelling can provide estimates of the arrival time and height of the wave and the area of inundation immediately after a tsunamigenerating event. But in the case of Palu, it appears that multiple landslides triggered by the earthquake caused the tsunami. In such unusual circumstances, tsunamis can occur in areas thought less prone to tsunami hazard.

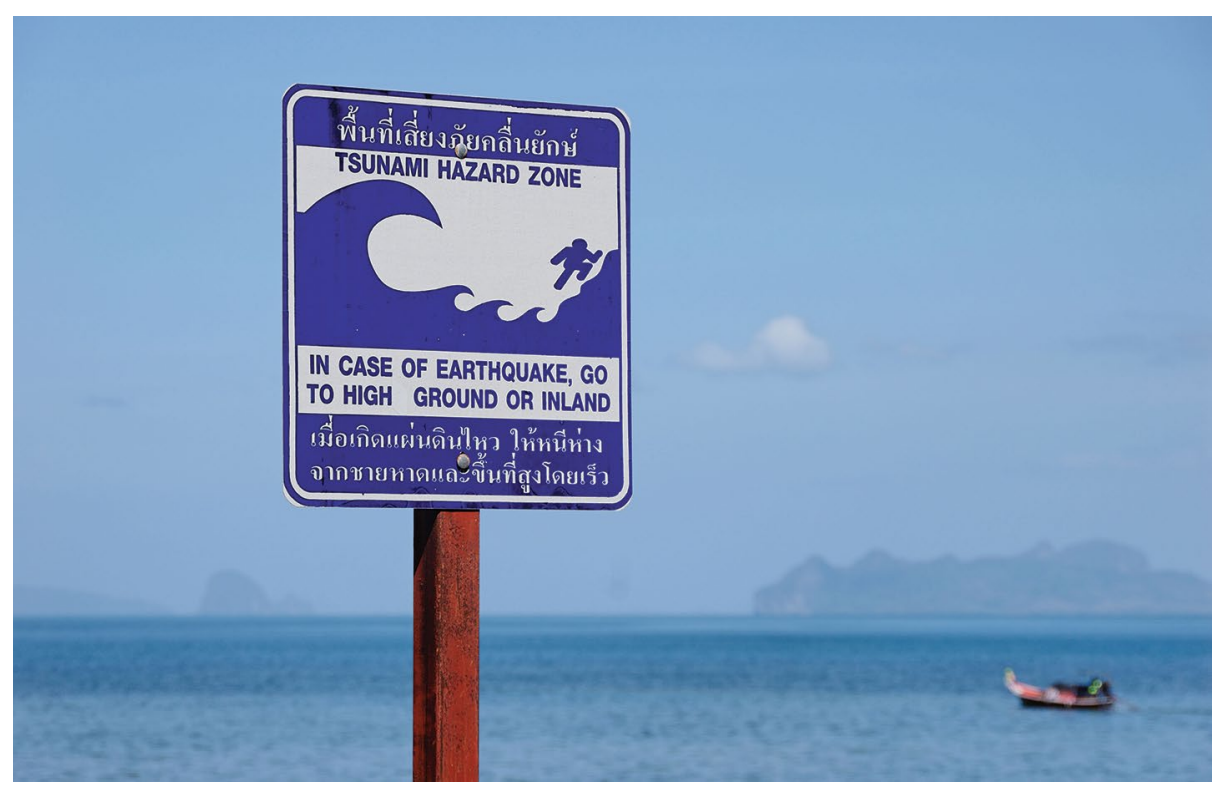

Tsunami hazard warning sign in Thailand. Credit: Contributor: Kevin Foy/Alamy Stock Photo

Early-warning networks consist of strategically placed cabled observatories and buoys ${ }^{2}$. The Deep-ocean Assessment and Reporting of Tsunamis (DART) system is most commonly used in early-warning networks. Sensors measure changes in seafloor temperature and pressure and transmit data via sea-surface buoys and satellite to an observatory. However, the cost of establishing and maintaining the system can be forbidding: a single monitoring DART station costs US\$500,000 (ref. ${ }^{2}$ ). Indeed, none of the 22 DART stations around Indonesia, which are part of the wider Indian Ocean early-warning network, have been operational since 2012 because the cost of maintenance has been too high ${ }^{3}$.

The second tsunami, from the flank collapse of Anak Krakatau during its eruption in December 2018, had been pre-empted in computer simulations back in 2012 (ref. ${ }^{4}$ ). The rarity of tsunamis generated by volcanic collapses has meant that early-warning systems in Indonesia, where resources are limited, tend to be focused on earthquakes.

Perhaps the most cost-effective measure to reduce tsunami hazard is risk communication. We need projects that educate people about the dangers of tsunamis and how to protect themselves. One such example is the Strengthening
School Preparedness for Tsunami in Asia and the Pacific project run by the United Nations Development Programme. To date the programme has had 61,175 students and staff from schools across 18 countries in Asia and the Pacific region take part in tsunami drills ${ }^{5}$. In addition, workshops are run to develop evacuation maps and plans for individual schools.

The 2018 Indonesian tsunamis once again demonstrate the vast destructive power of natural hazards. While people continue to depend on living on tsunamiprone coasts for their livelihoods, research, engineering and education must work together to protect them by building affordable early-warning systems at the same time as knowledge and resilience against these deadly hazards.

Published online: 27 February 2019 https://doi.org/10.1038/s41561-019-0328-4

References

1. Rubin, C. M. et al. Nat. Commun. 8, 16019 (2017)

2. Bernard, E. \& Titov, V. Phil. Trans. R. Soc. A 373, 20140371 (2015).

3. Indonesia tsunami: death toll from Anak Krakatau volcano rises. BBC News (25 December 2018); https://go.nature.com/2tthCcF

4. Giachetti, T. et al. Geol. Soc. Spec. Publ. 361, 79-90 (2012).

5. Strengthening school preparedness for tsunamis in Asia and the Pacific. UNDP in Asia and the Pacific (accessed 12 February 2019); https://go.nature.com/2SL71sI 